\title{
Challenges to Implementing Food Safety and Produce Handling Training in School Meal Programs
}

\author{
Sandra C. Curwood, PhD, RDN (Corresponding author) \\ School Nutrition Programs Director, Virginia Department of Education \\ 101 North 14th Street, Richmond, VA 23219, United States \\ Tel: 1-804-371-2339 E-mail: sandra.curwood@doe.virginia.gov
}

\begin{abstract}
Susan W. Arendt, PhD, RD, FAND
Professor in Hospitality Management

Associate Chair for Undergraduate Academic Affair, Iowa State University 9E MacKay Hall, 2302 Osborn Drive, Ames, Iowa 50011, United States Tel: 1- 515-294-7575Ｅ-mail: sarendt@iastate.edu
\end{abstract}

Lakshman Rajagopal, PhD

Associate Professor in Hospitality Management, Iowa State University 31MacKay Hall, 2302 Osborn Drive, Ames, Iowa 50011, United States

Tel: 1- 515-294-9740 E-mail: 1raj@iastate.edu

\begin{abstract}
Stephen W. Sapp, PhD
Professor in Sociology, Iowa State University 320 East Hall, 510 Farm House Lane, Ames, Iowa, 50011, United States

Tel: 1-515-294-1403Ｅ-mail: ssapp@iastate.edu
\end{abstract}
Received: August 9, 2017 Accepted: September 2, 2017 Published: September 4, 2017 doi:10.5296/jfs.v6i1.11669 URL: https://doi.org/10.5296/jfs.v6i1.11669




\section{MlMacrothink}

\section{Abstract}

This study explored school foodservice directors' (FSDs') attitudes, influencers, knowledge about safe produce handling, and perceived challenges related to food safety training using Ajzen's (1985) theory of planned behavior (TPB) as a theoretical underpinning. A web-based questionnaire was developed, pilot tested, and sent to all 864 public school districts in California. Demographic data, knowledge scores, attitudes, influencers, and challenges are reported using descriptive statistics and t-tests. Most respondent school FSDs ( $\mathrm{n}=136$, response rate of $16.4 \%$ ) were female, between the ages of 35-64, with a least a bachelors' degree, and more than 10 years of school foodservice experience. Most districts were self-operated, small, at least $50 \%$ free and reduced eligibility, and had conventional kitchens with speed-scratch preparation. School FSDs' attitude towards offering food safety training had the highest level of agreement regarding maintaining department reputation. The health inspector was identified as having the greatest likelihood to think food safety training should be offered. The noted perceived challenge to providing food safety training was "employee scheduling availability." Findings identified $84.4 \%(\mathrm{n}=108)$ of respondents had a Certified Food Safety Protection (CFPM) certification and $12.6 \%(n=16)$ attended USDA's Produce Safety University (PSU) with no significant differences in knowledge scores based on either having attended USDA's PSU or having CFPM certification. Regarding knowledge questions, 24.4\% answered all six correctly $(n=125-127)$. School foodservice staff need adequate food safety training and safe produce handling practices as part of their food safety management plan. Produce safety training can be supported by state agencies and professional organizations.

Keywords: Food safety, Produce handling, Professional development, School foodservice, Theory of planned behavior, Training

\section{Introduction}

School foodservice directors have a responsibility to uphold and promote food safety in school nutrition programs to maintain student health and well-being. According to United States Federal Drug Administration Food Code, school-aged children are susceptible to foodborne illnesses and require additional safeguards (U.S. Food and Drug Administration [FDA], 2014).

The Child Nutrition and WIC Reauthorization Act of 2004 required school nutrition programs to implement food safety programs based on hazard analysis and critical control points (HACCP) principles (United States Department of Agriculture, Food and Nutrition Services, 2004) USDA, FNS, 2004). Two health inspections are required annually for each school (USDA, FNS, 2014). Specifically, the need to address produce safety in school nutrition programs has been identified by USDA through programs, such as Produce Safety University (USDA, FNS, 2013) and Serving Up Science: The Path to Safe Food in Schools (Serving Up Science, 2015).

Preventing foodborne illness is integral to food safety management. Using data from the U.S. Foodborne Disease Outbreak Surveillance System, Gould, Walsh, Vieira, Herman, Williams, Hall, and Cole (2013) identified the number of foodborne illness outbreaks in schools as 286; 


\section{$\triangle$ Macrothink}

representing 17,266 illnesses from 1998 to 2008. While the number of outbreaks was far less in schools than in restaurants $(7,939)$ or private homes $(1,058)$, the median number of illnesses per incident (38 in schools, compared to 5 in restaurants) was much greater. This emphasizes the importance of minimizing foodborne illness risk in schools. The CDC (2015) reported that most cases of foodborne illness go unreported or even undiagnosed.

Training is relevant in produce safety, as foodservice professionals are central to foodborne illness prevention. Foodservice professionals, including directors, managers, and employees require training to acquire job knowledge to perform their duties. Acquiring job knowledge and applying it in to practice supports organizational objectives, specifically in school foodservice; this includes maintaining a safe food environment that protects student well-being. Jones, Punia, Young, Huegli, and Zidenberg-Cherr (2013) conducted a statewide training needs assessment in California with $54.7 \%(n=422)$ respondent foodservice directors and supervisors identifying food safety training as being really needed or somewhat needed.

Professional standards for school nutrition programs became mandatory in July 2015 and include professional development requirements for all school foodservice staff (USDA, FNS, 2016). Specific standards include a minimum of six to twelve training hours depending on job category and cover four key topic areas with food safety and HACCP as training topics (USDA, FNS, 2016). All new school foodservice directors are now required to have eight hours of food safety training every five years (USDA, FNS, 2016).

The purpose of this study was to explore California school foodservice directors' attitudes, knowledge, beliefs, and identify challenges to providing food safety training related to produce handling in school foodservice programs. Ajzen's (1985) theory of planned behavior (TPB) was used as a theoretical underpinning for examining school foodservice directors' attitudes, influencers, challenges, and safe produce handling knowledge impact on food safety training. Attitudes in this study are based on personal judgement or experience as to whether an outcome will occur (Fishbein and Ajzen, 1980). Influencers rely on individuals' perceptions about the impact of others on their behavior, while challenges are related to their views of what resources are available to facilitate the behavior of food safety training (Ajzen, 2006).

\section{Methodology}

\subsection{Population}

The population included all California school foodservice directors as identified using the California Department of Education database (California Department of Education, 2015). School district foodservice departments may not each have a position with the title of foodservice director; therefore, the sample included the staff person designated as responsible for oversight of the foodservice department. In the 2015/16 school year, 864 California public school districts had school foodservice programs (California Department of Education, 2016).

Because food safety and state department requirements/guidelines vary by jurisdiction, only one state, California, was selected. California also has a long growing season and large crop variety that yields ample fresh produce available for school nutrition programs to utilize. 


\section{$\triangle$ Macrothink}

\subsection{Survey Instrument}

A web-based questionnaire was used. The survey instrument consisted of four parts. Part one contained 14 operations demographic questions such as number and type of schools in the district. Part two contained 24 items related to attitudes (8 items), influence of others (8 items), and perceived challenges related to food safety training ( 8 items). Questions related to attitude and influences of others and were adapted from Roberts (2008) examining restaurant managers' behavioral intention regarding food safety training. Slight modifications were made by adding stakeholders specific to school district settings. DeVellis (2012) notes that Likert-type scales are used in studies measuring beliefs and attitudes and therefore, a Likert-type response scale was used. Part three included food safety knowledge (6 questions). Six multiple choice questions were used to assess school foodservice directors' knowledge about produce safety and Good Agricultural Practices (GAP) and Good Handling Practices (GHP). The question development process for this part was derived from food safety training materials (Institute of Child Nutrition, 2015), from the California Food Code 2015 (California Department of Public Health, 2015) and from USDA's GAP and (GHP materials (USDA, AMS, 2016). The items were scored as either correct or incorrect, with a total of zero to six points possible. Part four comprised 10 foodservice director demographic questions including attendance at USDA's PSU as well as certification as a food safety protection manager (CFPM). Dillman, Smyth, and Christian (2009) suggested placing more personal questions at the end of a survey and so these questions appeared last. Not all data collected are reported in this manuscript, as it is part of a larger study. Institutional Review Board approval was received prior to data collection.

\subsection{Data Collection}

To address questionnaire content validity and clarity, a pilot test was conducted with a convenience sample of ten school foodservice directors outside the state of California. In order to prevent cannibalization of the California school foodservice directors sample pool, another state in the USDA western region, Washington, was subsequently used for the pilot study. The questionnaire was modified based on respondent feedback; for example, in the introduction, a "don't know" response option was added encourage participants to continue completing the questionnaire if they did not know or have access to the information requested, potentially leading to an increased number of respondents completing the questionnaire. The questionnaire was emailed to all California school foodservice directors $(n=864)$.

\subsubsection{Data Analysis}

Data were analyzed using the Statistical Package for Social Sciences (SPSS) version 22 software. Descriptive statistics were utilized to analyze data distribution and included frequencies, means, and standard deviations for operational and foodservice director demographics. T-tests were utilized to analyze differences in mean scores between knowledge scores as well as operational and foodservice demographics.

Reliability for scales relating to the TPB was measured using Cronbach's alpha for internal consistency and was found to be: attitude towards food safety 0.92 , influencers of food safety 


\section{Macrothink}

training 0.91 , and challenges 0.88 . The desired threshold is 0.70 (Nunnally \& Bernstein, 1994) which was met.

Internal consistency reliability for knowledge questions was measured using Kuder-Richardson 20 test with a value of 0.827 (with a range between 0 and 1). The reliability score was considered acceptable. The value indicates discernment between those who know the material versus those who do not. However, if the value was over 0.90, Kuder and Richardson (1937) indicated the test would not demonstrate any difference in knowledge, as if the same question was being asked in this example, six times.

\section{Results and Discussion}

\subsection{School Foodservice Director Demographics}

The web-based questionnaire yielded usable response rate of $16.4 \%(n=136)$. Table 1 contains respondent demographic characteristics. Close to half $(45.6 \%)$ of respondents were over the age of 50 , and $84.4 \%$ were female, with $60.9 \%$ of respondents holding a bachelor's degree or higher. A foodservice director title was held by $92.7 \%$. The majority of respondents $(85.2 \%)$ had worked in school foodservice for over three years with $61.4 \%$ having been in their current position more than three years. Findings identified $84.4 \%(n=108)$ of respondents had a CFPM certification and $12.6 \%(n=16)$ had attended USDA's Produce Safety University.

Table 1. Questionnaire respondent's demographics ( $\mathrm{n}=124-137)$

\begin{tabular}{lll}
\hline Category & Frequency $(n)$ & Percent $(\%)$ \\
\hline Age & 2 & 1.6 \\
18-25 years old & 18 & 14.2 \\
$26-34$ years old & 49 & 38.6 \\
35-49 years old & 56 & 44.0 \\
$50-64$ years old & 2 & 1.6 \\
65 years old or older & & \\
Gender & 108 & 84.4 \\
Female & 20 & 15.6 \\
Male & & \\
Highest Level of Education & 10 & 7.8 \\
High school & 40 & 31.3 \\
Some college & 51 & 39.8 \\
Bachelor's degree & 27 & 21.1 \\
Graduate degree & & \\
Job Title & 127 & 92.7 \\
Foodservice Director & 10 & 7.3 \\
Other & & \\
Years Worked in School Foodservice & 19 & 14.8 \\
0 to 3 & 23 & 18.0 \\
4 to 6 &
\end{tabular}


More than 10

14

72

10.9

Years in current position

0 to 3

4 to 6

7 to 10

More than 10

Certified Food Protection Manager ${ }^{\text {a }}$

Attended USDA's Produce Safety University ${ }^{a}$

Note: ${ }^{\text {a }}$ Yes responses.

\subsection{School District Demographics}

Table 2 displays school district and departmental operational demographics. The number of schools per district ranged from one to 230 , with over half $(58.6 \%)$ having less than 10 schools. The highest percent of districts $(92.0 \%)$ included elementary schools, $82.5 \%$ had middle schools, and $62 \%$ had high schools. School district enrollment size categories were determined from the USDA, FNS professional guidelines. USDA mandated professional development standards are based on these three school district size levels (USDA, FNS, 2016). District enrollment ranges were fairly equally distributed between the three categories, with $39.0 \%$ having 2,499 students or less, $29.4 \%$ of districts with 2,500-9,999 students and $31.6 \%$ having 10,000 or more students.

\subsection{Department Operational Demographics}

Department operational demographics are displayed in Table 2. Most (89.9\%) school district foodservice departments were self-operated while only $10.1 \%$ were under contract management. Respondents were asked to indicate the types of kitchens in their departments as well as their methods of preparation. More than one selection was an option. Conventional onsite production was prevalent with $76.6 \%$ of respondents indicating they used this method. Additionally, 36.5\% had satellite sites, 33.6\% used a base kitchen with both onsite and distribution to site, $13.1 \%$ had central production with no onsite, $16.1 \%$ had a combination of types of kitchen production, and only $7.3 \%$ used a centralized commissary. The greatest number of respondents (62.8\%) indicated using the speed-scratch method of preparation, while $30.7 \%$ used mostly the pre-prepared method, $8 \%$ used all-pre-prepared, $29.2 \%$ used assembly serve and the remaining $34.3 \%$ indicated they used a combination or another method of food preparation.

The greatest number of respondents $(62.2 \%)$ served 500 or fewer breakfast meals daily with only $9.0 \%$ serving more than 3,000 per day. Just over half of the districts $(51.2 \%)$ surveyed served more than 1,000 lunch meals. Less than half (47.2\%) served between 301-3,000 snacks daily and two-thirds $(67.7 \%)$ of respondents served 350 or less supper meals. 


\section{Macrothink}

Table 2. District and department operational characteristics $(n=118-137)$

\begin{tabular}{|c|c|c|}
\hline Category & Frequency $(n)$ & Percent $(\%)$ \\
\hline \multicolumn{3}{|l|}{ Number of Schools in District } \\
\hline $1-9$ & 78 & 58.6 \\
\hline $10-29$ & 43 & 32.3 \\
\hline $30-59$ & 7 & 5.3 \\
\hline $60-89$ & 4 & 3.0 \\
\hline $90+$ & 1 & 0.8 \\
\hline \multicolumn{3}{|l|}{ Types of Schools in District ${ }^{a}$} \\
\hline Elementary & 126 & 92.0 \\
\hline Middle & 113 & 82.5 \\
\hline High & 85 & 62.0 \\
\hline \multicolumn{3}{|l|}{ School District Enrollment } \\
\hline 2,499 or fewer & 53 & 39.0 \\
\hline $2,500-9,999$ & 40 & 29.4 \\
\hline 10,000 or more & 43 & 31.6 \\
\hline \multicolumn{3}{|l|}{ Students Eligible for Free or Reduced Price Meals } \\
\hline $0-24 \%$ & 19 & 13.9 \\
\hline $25-49 \%$ & 23 & 16.8 \\
\hline $50-74 \%$ & 51 & 37.2 \\
\hline $75-100 \%$ & 44 & 32.1 \\
\hline \multicolumn{3}{|l|}{ Management Type } \\
\hline Self-operated & 115 & 89.9 \\
\hline Contract & 12 & 10.1 \\
\hline \multicolumn{3}{|l|}{ Types of Kitchens ${ }^{b}$} \\
\hline Conventional Onsite & 105 & 76.6 \\
\hline Centralized (commissary) & 10 & 7.3 \\
\hline Base Kitchen (onsite preparation and distribution) & 46 & 33.6 \\
\hline Central Production (no onsite service) & 18 & 13.1 \\
\hline Satellite Sites & 50 & 36.5 \\
\hline Combination & 22 & 16.1 \\
\hline \multicolumn{3}{|l|}{ Type of Preparation ${ }^{b}$} \\
\hline Speed Scratch & 86 & 62.8 \\
\hline Mostly pre-prepared & 42 & 30.7 \\
\hline All pre-prepared & 11 & 8.0 \\
\hline Assembly-Serve & 40 & 29.2 \\
\hline Combination and Other & 47 & 34.3 \\
\hline \multicolumn{3}{|l|}{ Daily Average Number of Breakfasts Served } \\
\hline 500 or less & 69 & 62.2 \\
\hline $501-3,000$ & 32 & 28.8 \\
\hline $3,001-12,000$ & 7 & 6.3 \\
\hline 12,001 or more & 3 & 2.7 \\
\hline Daily Average Number of Lunches Served & & \\
\hline
\end{tabular}


1,000 or less

$1,001-10,000$

$10,001-50,000$

$50,001-100,000$

100,001 or more

Daily Average Number of Snacks Served

300 or less

$301-3,000$

$3,001-10,000$

10,001 or more

Daily Average Number of Suppers Served

350 or less

$351-2,000$

$2,001-10,000$

10,001 or more

Note: ${ }^{a}$ Some school district have all three school types.

${ }^{\mathrm{b}}$ Greater than $100 \%$ due to multiple options possible.

\subsection{Attitudes towards Food Safety Training}

Survey questions addressed foodservice directors' attitudes towards food safety training including benefits, influences, and perceived challenges. Attitude was assessed using foodservice directors' beliefs as to why food safety training should be offered, including department reputation and management responsibility. Respondent school foodservice directors' attitude towards offering their staff food safety training found statements with highest level of agreement regarding maintaining department reputation included "increasing employees' awareness of food safety" $(\mathrm{M}=6.59$, on a seven point Likert -type scale, with 1 being extremely unlikely and 7 being extremely likely, $S D=0.97)$ and "ensure safe food" $(M=$ 6.56, $\mathrm{SD}=0.97$ ), while the lowest levels of agreement were related to management responsibility for "reduce food cost" $(\mathrm{M}=5.39, \mathrm{SD}=1.75)$, and "keeping my supervisor happy" $(\mathrm{M}=5.69, \mathrm{SD}=1.67)$.

\subsubsection{Influencers}

Influencers, benefits, and challenges to providing food safety training are listed in Table 3. Respondents were asked about the impact that other individuals as stakeholders (important to their work) had in influencing their attitude towards food safety training. The health inspector $(\mathrm{M}=6.59, \mathrm{SD}=1.18)$ and immediate supervisor $(\mathrm{M}=6.25, \mathrm{SD}=1.36)$ were the individuals identified by school foodservice director's as having the greatest likelihood to think that food safety training should be offered. Two health inspections are required annually for each school (USDA, 2014) and are conducted by inspectors from the local public health departments. The Food and Drug Administration's Food Code is the source used by health inspecting agencies to develop their food safety guidelines (FDA, 2014). The health 
inspections are unannounced and the results are made available to the public; major or repeat violations require corrective action, follow up visits, and potential facility closure and monetary penalties. Therefore, it is not surprising that foodservice directors ranked the health inspector highest in offering food safety training based on their potential influence on maintaining the departments' reputation. Conversely, vendors $(\mathrm{M}=5.27, \mathrm{SD}=1.69)$ and short-term employees (employed less than two-years) $(\mathrm{M}=5.68, \mathrm{SD}=1.46)$ were identified as least likely.

\subsubsection{Challenges to Providing Food Safety Training}

Survey results indicated that the challenge to provide food safety training with highest level of agreement was "employee scheduling availability" $(\mathrm{M}=5.34, \mathrm{SD}=1.76)$ and "time commitment for training" $(\mathrm{M}=5.08, \mathrm{SD}=1.82)$. The lowest level of agreement was "employees don't practice what they learn from training" $(\mathrm{M}=3.50, \mathrm{SD}=1.93)$ and "lack of targeted materials" $(\mathrm{M}=3.69, \mathrm{SD}=1.97)$. These findings suggest that the perceived challenges identified by school foodservice directors' are more likely related to scheduling and time available for training rather than employees' response to training or lack of targeted materials.

Table 3. Influencers, benefits and challenges to food safety training $(n=133-137)$

\section{$\mathrm{M}^{\mathrm{a}}$}

SD

a. Likelihood the listed individuals will think that you should offer

food safety training to your employees.

Health inspector

$6.59 \quad 1.18$

Immediate supervisor

$6.25 \quad 1.36$

District superintendent

$6.20 \quad 1.25$

Customers (students, parents, faculty)

$6.15 \quad 1.18$

Board of Education

$6.07 \quad 1.36$

Long-term employees

$5.87 \quad 1.47$

Short-term employees (less than 2 years)

$5.68 \quad 1.46$

Vendor(s)

$5.27 \quad 1.69$

Total Influence of others

$6.01 \quad 1.37$

b. Food safety training will...

$\begin{array}{lll}\text { Increase employees' awareness of food safety } & 6.59 & 0.97\end{array}$

Ensure safe food

$6.56 \quad 0.97$

Help maintain the department reputation

$6.49 \quad 1.06$

Decrease the likelihood of lawsuits

$6.27 \quad 1.20$

Keep customers satisfied

$5.92 \quad 1.50$

Increase employee satisfaction

$5.82 \quad 1.37$

Keep supervisor satisfied

$5.69 \quad 1.67$

Reduce food cost

$5.39 \quad 1.75$

Overall Benefit Mean Score

$6.09 \quad 1.37$

c. Challenges to provide food safety training 
Employee scheduling availability

Time commitment for training

Managers' time

Financial resources

Lack of on-site opportunities

Lack of off-site opportunities

Lack of targeted materials

Employees don't practice what they learn from training

Overall Challenges Mean Score

${ }^{\mathrm{a}}$ Rating scale: $1=$ extremely unlikely to $7=$ extremely likely.

\subsection{Produce Safety Knowledge}

School foodservice director knowledge was tested by answering a series of six produce safety and GAP related questions. Findings revealed only $24.4 \%$ of responding foodservice directors answered all six questions correctly and $32.3 \%$ missed only one question $(n=125-127)$. The question most frequently missed was regarding fresh produce handling and storage (i.e. GHP) with just over half (57.9\%) answering correctly. A question related to GAPs regarding receiving fresh produce were answered correctly by $59.2 \%$ and a question about acceptable delivery practices were answered correctly by $66.4 \%$. Temperature control, serving, and cross-contamination questions were answered correctly, $79.2 \%, 99.2 \%$ and $100 \%$ respectively.

\subsubsection{Foodservice Director Demographics and Produce Safety Knowledge}

CFPM certification was held by $84.4 \%(n=108)$ of respondent FSDs with $12.6 \%(n=16)$ having attended USDA's Produce Safety University. Having attended PSU ( $n=16)$ was associated with a mean produce safety knowledge score of $5.00(\mathrm{SD}=0.89)$ in comparison with FSDs not having attended PSU resulting in a mean produce safety knowledge score of $4.64(\mathrm{SD}=0.99)$. An independent samples $t$-test was performed, revealing no significant differences in knowledge scores of respondents based on either having attended USDA's Produce Safety University (PSU) $(\mathrm{p}=.095)$ or having certification as a Food Protection Manager (CFPM), which includes certifications such as ServSafe ${ }^{\circledR}$ and the National Registry of Food Safety Professionals $(p=.129)$. It should be noted that the limited number of respondents may impact results. Other FSD demographics including education level, age, sex, and years in school foodservice did not yield any statistically significant difference in mean knowledge scores. Table 4 contains mean produce safety knowledge scores compared to characteristics respondents, school districts, and foodservice department operations.

\subsubsection{School District and Department Characteristics and Produce Safety Knowledge}

Foodservice directors in school districts with greater than 2,499 students were noted to have significantly $(\mathrm{p} \leq 0.00)$ higher mean knowledge scores $(\mathrm{M}=4.92, \mathrm{SD}=0.96)$ than their counterparts with fewer students $(\mathrm{M}=4.27, \mathrm{SD}=0.92)$. Respondents identifying their district foodservice as self-operated $(n=115)$ had a significantly $(\mathrm{p}=.025)$ higher mean food safety knowledge score $(M=4.73, S D=1.01)$ compared to districts $(n=12)$ contracting a management 
company $(\mathrm{M}=4.25, \mathrm{SD}=0.62)$. However, these results are based on a small sample size and therefore may not reflect the greater population. School FSDs in smaller districts $(2,499$ or less students) may have fewer resources available for training, while potentially maintaining the same number of areas of responsibility.

Table 4. Produce safety knowledge compared to respondent demographics and district and department operational characteristics and influence of others $(n=118-137)$

Respondent Foodservice Director Demographics

\begin{tabular}{|c|c|c|c|}
\hline & $\mathrm{N}$ & $\begin{array}{l}\text { Mean (M) Knowledge } \\
\text { Scores }^{\text {a }}\end{array}$ & SD \\
\hline \multicolumn{4}{|l|}{ Foodservice Director Age (Years) } \\
\hline Less than 50 & 19 & 4.68 & 1.01 \\
\hline 50 or Older & 106 & 4.63 & 0.90 \\
\hline \multicolumn{4}{|l|}{ Foodservice Director Education } \\
\hline Less than a Bachelor's Degree & 77 & 4.90 & 0.96 \\
\hline Bachelor's Degree or Higher & 49 & 4.33 & 0.92 \\
\hline \multicolumn{4}{|l|}{ Years in School Foodservice } \\
\hline Less than 7 & 41 & 4.65 & 0.94 \\
\hline 7 or More & 86 & 4.68 & 1.01 \\
\hline \multicolumn{4}{|l|}{ Sex } \\
\hline Male & 19 & 4.95 & 0.97 \\
\hline Female & 107 & 4.63 & 0.99 \\
\hline Food Protection Manager Certification & & $\begin{array}{l}\text { Mean (M) Knowledge } \\
\text { Scores }^{\text {a }}\end{array}$ & $\mathrm{SD}$ \\
\hline Yes & 108 & 4.69 & 1.02 \\
\hline No & 19 & 4.68 & 0.82 \\
\hline \multicolumn{4}{|l|}{ Produce Safety University Attendance } \\
\hline Yes & 16 & 5.00 & 0.89 \\
\hline No & 111 & 4.64 & 0.99 \\
\hline $\begin{array}{l}\text { District and Department Operational } \\
\text { Characteristics } \\
\text { Management Type }\end{array}$ & & & \\
\hline Self-operated & 115 & 4.73 & 1.01 \\
\hline Contract & 12 & 4.25 & 0.62 \\
\hline \multicolumn{4}{|l|}{ Number of Students } \\
\hline $1-2,499$ & 77 & 4.92 & 0.96 \\
\hline 2,500 or more & 48 & 4.27 & 0.92 \\
\hline
\end{tabular}

${ }^{\text {a }}$ Knowledge scores range 0 to 6 . 


\section{Conclusions}

Handling produce safely is important in school nutrition programs. School foodservice staff requires adequate food safety training to maintain a food safe operation, which includes safe produce handling, and is integral to their food safety management plan.

Foodservice professionals, including directors, managers, and employees, require training to acquire job knowledge to perform their duties. Acquiring job knowledge and applying it in practice supports organizational objectives. In the school district setting, organizational objectives include student well-being. Training in the workplace is imperative for staff at all levels and has been identified in the literature as essential to facilitate meeting organizational objectives (Bartel, 1991; Delaney \& Huselid, 1996). Conversely, Poulston (2008) in a hospitality study noted that lack of adequate training was related to increased disciplinary problems and staff turnover. Knowledge acquisition can be acquired through training, but also occurs via observation of other employees, as well as with use of consultants and specialists. Previous studies with foodservice managers have noted that challenges to providing staff training include time, funding, and demographic differences (Arendt, Paez, \& Strohbehn, 2013; Sneed \& Strohbehn, 2008).

Most foodservice directors identified staff schedule availability and adequate time to train as perceived challenges to providing food safety training. While many resources and training materials were identified as being available for general food safety training, materials targeted to handling produce safely and GAP information may not be as well-known. The increased use of fresh produce and farm-to-school activities (USDA, FNS, 2016) demonstrates the increased need for availability of these resources in formats accessible and available to be delivered when time and scheduling are a challenge. Respondent school foodservice directors indicated recognition of the importance to other key stakeholders of food safety training. Communicating the importance of food safety training and safe produce handling to key stakeholders can be supported by State agencies and professional organizations.

While most school foodservice directors have a certified food protection manager certificate $(84 \%)$, there is room for improvement. Produce safety knowledge testing indicated that there was no significant difference in food safety knowledge scores between directors with and without food safety certification. However, school foodservice directors are required to have food safety training and thus need this knowledge to operate a school nutrition program.

Recent programmatic changes have increased produce available in schools via the Healthy Hunger Free Kids Act of 2010 (USDA, FNS, 2014), which requires increased fruits and vegetables to be available in the National School Lunch Program (NSLP). In an Indiana study evaluating the methods and challenges in implementing the new NSLP regulations, methods noted by respondents to incorporate vegetables into the menu included $87.0 \%(n=94)$ served as sides and $49.1 \%(n=53)$ noted that they served vegetables in salad bars (Thiagarajah, Getty, Johnson, Case, \& Herr, 2015). The proliferation of salad bars in schools and increased participation of school districts in Farm to School (F2S) programs coincides with produce safety concerns and the recent associated foodborne illness rates. This increased use of fresh produce in schools has also increased the need for GAP/GHP awareness by school foodservice 
directors. FSD knowledge scores suggest that practice may have outpaced training and resources related to produce safety.

\subsection{Professional Development Needs}

Arendt, Paez, and Strohbehn (2013) noted that foodservice managers perceive staff turnover and limited time as barriers to making sure that staff adheres to established food safety practices. Sneed and Strohbehn (2008) noted as a trend that generational and ethnic diversity in foodservice creates a need for the manager to customize food safety training and is facilitated by online and technology resources. Strohbehn, Jun, and Arendt (2014) found that $98.2 \%(n=754)$ of school foodservice employee study participants had received some food safety training and concluded that tailoring the delivery method based on employee age group and number of hours worked could improve food safety practices. Technology continues to advance at a rapid rate and can support food safety training but also comes with an associated cost and an expected learning curve. Recognizing training strategies that apply to the needs of the adult learner can aid managers in improving training effectiveness. Strohbehn, Arendt, Ungku, and Meyer (2013) found that offering a variety of food safety training formats such as face-to-face delivery and computer based, could be used with adult learners. The authors noted that food safety tool kits used in a variety of delivery formats could be effectively used by foodservice managers.

\subsection{Food Safety Training}

According to the Centers for Disease Control and Prevention (2014), the three most common food safety errors contributing to unsafe food and foodborne illness are food handling errors, poor personal hygiene, and cross-contamination. Painter, Hoekstra, Tauxe, Braden, Angulo, and Griffin (2013) found that of the 17 food commodity categories, produce had the highest percentage $(46 \%)$ of attributed foodborne illness cases; further emphasizing the importance of food safety training and safe produce handling.

The research findings comparing the effectiveness of training with food safety practice compliance have been conflicting. As with this study, foodservice director's knowledge scores were essentially the same whether they had certification as a food safety protection manager (CFPM) or not. In one observational study conducted in 40 schools in Iowa concerning foodservice operations, Henroid and Sneed (2004) reported that there was no difference in food safety knowledge noted between staff having taken a food safety certification course $(64.4 \%)$ and staff not completing a course $(35.6 \%)$. However, food safety practice scores were higher for staff (managers and employees) that had completed a food safety certification course. The authors found no significant differences in food safety practice scores based on personal demographics of age, education, or experience nor were there differences based on operational demographics such as number of schools or amount and type of staff.

FSD knowledge mean scores were found to be higher in medium and larger school districts (with more than 2,499), possibly indicating that smaller districts have less training and fewer resources available. Additionally, self-operated districts had a higher knowledge mean scores 


\section{MInstitute ${ }^{\text {Mink }}$}

than the respondents with contract management; however the sample size was small and therefore may not be reflective of the population.

Professional standards for school nutrition programs became mandatory in July 2015 and include professional development requirements for all school foodservice staff (USDA, FNS, 2016). Specific standards include a minimum of six to twelve training hours depending on job category and cover four key topic areas with food safety and HACCP as one of six training topics (USDA, FNS, 2016). All school foodservice directors are now required to have eight hours of food safety training every five years (USDA, FNS, 2016). Produce Safety University, a five-day program sponsored by USDA that provides in-depth hands on training for school nutrition programs, has not been widely available. Expanding participation opportunities and providing material in formats easily delivered to site staff may provide the additional produce safety specific materials to enhance school food safety training plans. Additionally, GAP and GHP training topics can be incorporated into existing food safety training materials.

Foodservice directors' attitudes, influencers, challenges, and knowledge regarding produce safety may impact their provision of food safety training. FSDs had the highest agreement scores with the health department inspector and their immediate supervisor had significant $(\mathrm{p}=$ 0.02) influence on their behavior. Therefore, maintaining the department's reputation was found to have the greatest influence on FSD's intention to offer food safety training.

The challenge facing school foodservice directors is in both maintaining food safety standards and safe produce handling required to support student well-being and managing the operational objectives both fiscally and from a human resources perspective. There are opportunities for state agencies and professional organizations to develop, provide a variety of training formats, and make these materials widely available to school foodservice directors.

\subsection{Limitations}

This study is not without constraints due to the small response rate. Recent programmatic changes may have possibly impacted FSDs workload and less focus for additional activities, such as participating in studies. Generalizations are therefore limited as the results from one state may not be representative across other states or regions.

\section{4 Future Research}

Future studies could expand the population to include other states and USDA regions and possibly compare regions nationally. Further expansion of the knowledge questions and separating basic produce handling from GAP/GHP questions might also yield more insight regarding foodservice director knowledge in these topic areas. 


\section{Macrothink Institute ${ }^{\mathrm{TM}}$}

The purpose of this study is to explore school foodservice directors' intentions to procure farm-to-school produce based on food safety practices.

\section{Definitions:}

Alternative produce procurement: Purchasing practices within geographic boundaries include, but are not limited to, purchasing directly from a grower, from a farmers market, through community supported agriculture, or via a regional food hub (USDA-FNS, 2014).

Traditional produce procurement: Also termed "conventional" procurement, this is described as purchasing through a broadline or wholesale foodservice distributor.

Part I: Operational Demographic Information. Please answer the following questions based on your school foodservice operation.

\section{Tell us about your district:}

1. In which of the following farm-to-school regions is your district located?

_ North Coast: Del Norte, Humboldt, Mendocino, Lake, Napa, Sonoma, Marin

_ North Valley: Butte, Glenn, Tehama, Colusa

_ Sacramento Valley: Sacramento, Yolo, Solano, Placer

_ Mother Lode: Calaveras, Tuolumne, Amador, EI Dorado

_ San Francisco Bay Area: San Francisco, San Mateo, Alameda, Contra Costa

_ Central Valley: San Joaquin, Stanislaus, Merced, Mariposa, Madera, Fresno, Kern, Tulare

_ Greater Los Angeles: Los Angeles, Riverside, San Bernardino

_ San Diego: San Diego, Orange

_ South Central Coast: San Luis Obispo, Santa Barbara, Ventura

2. How would you describe the setting of your school district?

Urban (population of more than 100,000 residents)

Suburban $(20,000-100,000$ residents) Rural (less than 20,000 residents)

3. How many students are enrolled in your district? 2499 or fewer

$$
\text { 2500-9,999 }
$$
10,000 or more

4. How many total schools are in your district?

Does your school district include: (check all that apply) Elementary school Middle School 
High School

5. Is your school foodservice department:

6. Please indicate the number of kitchen types in your district.

Conventional Onsite Kitchen (food prepared and served onsite)

Centralized (Commissary)

Base Kitchen (food served onsite as well as distributed offsite)

Central Production Kitchen(no on-site service)

Satellite Kitchen ( foods prepared offsite and delivered for onsite service)

Combination (Please describe)

7. How would you describe your preparation type? (Check all that apply)

_Speed-scratch" Mostly pre-prepared All pre-prepared Assembly-Serve Combination (Please describe): Other (Please describe):

8. What was the district-wide percentage of students eligible for free and reduced price meals on October 1, 2014 (CBEDS day)?

$0-24 \%$

$25-49 \%$ $50-74 \%$ $75-100 \%$

9. What was the average number of meals served daily in the 2014-15 school year?

Breakfast? Lunch? Snacks? Supper?

10. What was your total food cost in the 2014-15 academic year?

11. What was your total fresh produce cost 2014-15?

12. What percentage of your produce costs were from conventional procurement in the 2014-15 academic year? $0 \%$ $25 \%$ $50 \%$ $75 \%$ $100 \%$ 


\section{Macrothink}

13. What percentage of your produce costs were from farm-to-school (alternative) procured fresh produce in 2014-15? $0 \%$ $25 \%$ $50 \%$ $75 \%$ $100 \%$

14. What was your annual labor cost for 2014-15?

\section{Part II: Food safety training and produce procurement practices.}

For each statement below, please indicate your level of agreement using the scale.

15. Offering food safety training to my employees will

Strongly Agree Strongly Disagree
A. keep my supervisor satisfied
$\begin{array}{lllllll}1 & 2 & 3 & 4 & 5 & 6 & 7\end{array}$
B. keep my customers satisfied
$\begin{array}{lllllll}1 & 2 & 3 & 4 & 5 & 6 & 7\end{array}$
C. ensure safe food
$\begin{array}{lllllll}1 & 2 & 3 & 4 & 5 & 6 & 7\end{array}$
D. reduce food cost
$\begin{array}{lllllll}1 & 2 & 3 & 4 & 5 & 6 & 7\end{array}$
E. increase employees' awareness of food safety

$\begin{array}{lllllll}1 & 2 & 3 & 4 & 5 & 6 & 7\end{array}$
F. help maintain the department reputation

$\begin{array}{lllllll}1 & 2 & 3 & 4 & 5 & 6 & 7\end{array}$
G. increase employee satisfaction
$\begin{array}{lllllll}1 & 2 & 3 & 4 & 5 & 6 & 7\end{array}$
H. decrease the likelihood of lawsuits

$\begin{array}{lllllll}1 & 2 & 3 & 4 & 5 & 6 & 7\end{array}$

16. Please indicate the likelihood the listed individuals will think that you should offer food safety training to your employees

Extremely Likely

Extremely Unlikely
A. Your immediate supervisor
$1 \quad 2 \quad 3$
45
$6 \quad 7$
B. Your long-term employees
$12 \quad 3$
$\begin{array}{llll}4 & 5 & 6 & 7\end{array}$
C. Your short-term employees (less than 2 years)
123
45
$6 \quad 7$
D. Your customers (students, parents, faculty)

$\begin{array}{lllllll}1 & 2 & 3 & 4 & 5 & 6 & 7\end{array}$




\section{IMacrothink}

Journal of Food Studies

ISSN 2166-1073 2017, Vol. 6, No. 1
E. The health inspector
$\begin{array}{lllllll}1 & 2 & 3 & 4 & 5 & 6 & 7\end{array}$
F. Your vendor(s)
$\begin{array}{lllllll}1 & 2 & 3 & 4 & 5 & 6 & 7\end{array}$
G. Your board of education

$\begin{array}{lllllll}1 & 2 & 3 & 4 & 5 & 6 & 7\end{array}$
H. District superintendent
$\begin{array}{lllll}1 & 2 & 3 & 4 & 5\end{array}$
7

17. Please indicate your level of agreement as to whether the listed item makes it difficult to provide food safety training

Strongly Agree Strongly Disagree
A. Employee scheduling availability
$\begin{array}{lllllll}1 & 2 & 3 & 4 & 5 & 6 & 7\end{array}$
B. Managers' time
$\begin{array}{lllllll}1 & 2 & 3 & 4 & 5 & 6 & 7\end{array}$
C. Financial resources
$\begin{array}{lllllll}1 & 2 & 3 & 4 & 5 & 6 & 7\end{array}$
D. Lack of off-site opportunities
$\begin{array}{lllllll}1 & 2 & 3 & 4 & 5 & 6 & 7\end{array}$
E. Lack of on-site opportunities
$\begin{array}{lllllll}1 & 2 & 3 & 4 & 5 & 6 & 7\end{array}$
F. Lack of targeted materials
$\begin{array}{lllllll}1 & 2 & 3 & 4 & 5 & 6 & 7\end{array}$
G. Employees don't follow what they learn from training
$\begin{array}{lllllll}1 & 2 & 3 & 4 & 5 & 6 & 7\end{array}$
H. Time commitment for training
$\begin{array}{lllllll}1 & 2 & 3 & 4 & 5 & 6 & 7\end{array}$

18. Please indicate how STRONGLY you agree or disagree with the following statements

$\begin{array}{ll}\text { Strongly } & \text { Strongly } \\ \text { Agree } & \text { Disagree }\end{array}$

A. Most people who are important to me think that I should purchase $\quad 1 \quad \begin{array}{lllllll}2 & 3 & 4 & 5 & 6 & 7\end{array}$ produce using alternative procurement methods.

B. The people in my professional life whose opinions I value would $11 \quad 2 \quad \begin{array}{llllll}3 & 4 & 5 & 6 & 7\end{array}$ approve of me purchasing produce directly from farmers within the next 
year.

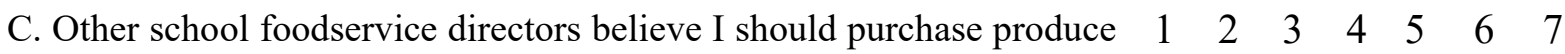
using alternative procurement methods.

D. The California Department of Education supports purchasing $1120 \begin{array}{llllll}2 & 2 & 4 & 5 & 6 & 7\end{array}$ produce from alternative procurement methods.

19. Please indicate how STRONGLY you agree or disagree with the statements.

$\begin{array}{ll}\text { Strongly } & \text { Strongly } \\ \text { Agree } & \text { Disagree }\end{array}$

A. Most California School Boards of Education believe alternative $1120 \begin{array}{llllll}2 & 3 & 4 & 5 & 6 & 7\end{array}$ produce procurement methods should be used in school foodservice.

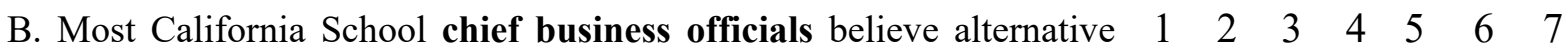
produce procurement methods should be used in school foodservice.

C. Most California school district superintendents believe it is $1 \begin{array}{lllllll}2 & 2 & 3 & 4 & 5 & 6 & 7\end{array}$ important to purchase produce from alternative procurement sources.

D. Most students believe it is important to purchase produce using $1120 \begin{array}{llllll} & 2 & 4 & 5 & 6 & 7\end{array}$ alternative procurement sources.

E. Most parents believe it is important to purchase produce from $1 \begin{array}{llllllll}1 & 2 & 3 & 4 & 5 & 6 & 7\end{array}$ alternative procurement sources.

\section{Please indicate how STRONGLY you agree or disagree with the following statements.}

$\begin{array}{ll}\text { Strongly } & \text { Strongly } \\ \text { Agree } & \text { Disagree }\end{array}$

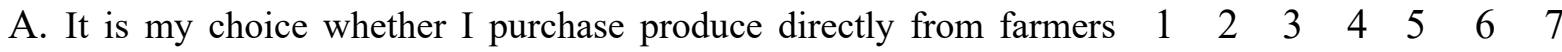 during the next year.
B. I will try to purchase produce directly within the next year.
$\begin{array}{lllllll}1 & 2 & 3 & 4 & 5 & 6 & 7\end{array}$
C. I am able to purchase produce directly if I choose.
$\begin{array}{lllllll}1 & 2 & 3 & 4 & 5 & 6 & 7\end{array}$ 
D. I plan to purchase produce directly within the next year.

$\begin{array}{lllllll}1 & 2 & 3 & 4 & 5 & 6 & 7\end{array}$

\section{Please indicate how STRONGLY agree or disagree with the statements.}

$\begin{array}{ll}\text { Strongly } & \text { Strongly } \\ \text { Agree } & \text { Disagree }\end{array}$

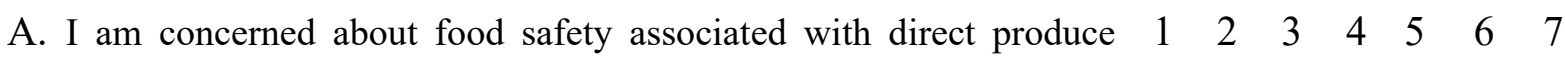
purchasing.

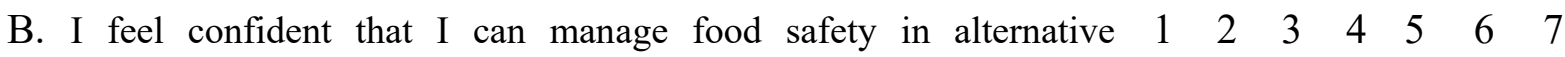
produce purchasing.

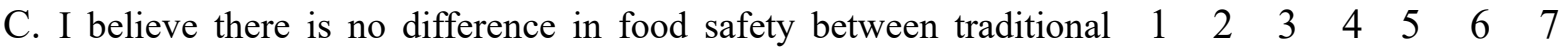
and alternate produce purchasing.

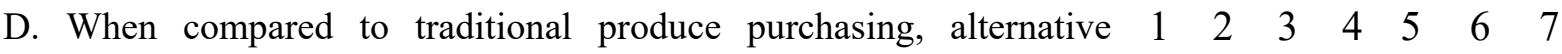
purchasing has more safety concerns.

22. For each statement below, please indicate how likely or unlikely you are to take action.

$\begin{array}{ll}\text { Extremely } & \text { Extremely } \\ \text { Likely } & \text { Unlikely }\end{array}$

A. I intend to use alternative produce purchasing in my operation during $\quad 1 \quad 2 \quad \begin{array}{llllll}3 & 4 & 5 & 6 & 7\end{array}$ the next year.

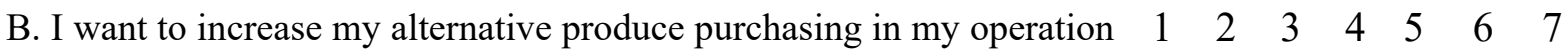
during the next year.

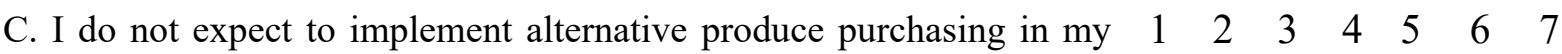
operation during the next year.

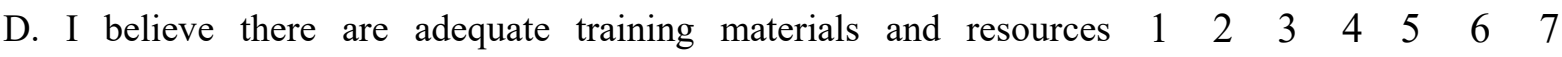
available for me to purchase produce using alternative procurement methods.

Food Safety Knowledge (Based on the 2015 California Food Code and Good Agricultural Practices (GAP), please answer the questions below): 
23. What food is NOT considered time/temperature controlled for safety (TCS)? (Select one)

Frozen corn ___ Pizza __ Whole tomatoes

\section{Chopped lettuce ___ Chicken nuggets}

24. Select the TRUE statement. Unprocessed produce should be delivered: in a new, single-use container.

in a reused cardboard produce box

in a plastic-lined sealed container.

loose in the back of a pickup truck.

25. Which of following practice is correct in a foodservice operation?

Store washed and unwashed fruits and vegetables together.

Wash fresh tomatoes before storing.

Handle ready-to-eat vegetables without gloves.

Use packaged, washed, ready-to-eat spinach without rinsing.

26. A salad bar with eight different items on it, must have how many serving utensils?

$2 \quad 4 \quad 6 \quad 6 \quad 8$

27. What is the concern with storing raw chicken above romaine lettuce in the refrigerator?

Cross-contamination

Time-temperature abuse
Poor personal hygiene

Lettuce tastes like chicken

28. Which one of the following statements is FALSE: Unprocessed fresh produce should be rejected if:

specifications are not met there is evidence of pests there is evidence of product abuse if the product temperature is over $41^{\circ} \mathrm{F}$ 


\section{Macrothink}

\section{Part III: Foodservice Director Demographic Information.}

\section{Tell us about yourself:}

29. What is your job title?

Foodservice Director

Foodservice Supervisor
Foodservice Manager

Other: (list)

30. Which of the following job duties do you perform? (Check all that apply)

_. Menu planning

Staff hiring

Staff evaluation

Preparation of meals
Recipe development Staff training

Purchasing of foods

Inventory management
Budget management Staff supervision Receiving of products

Marketing of the program

Other (please specify)

31. How many hours per week do you work in school foodservice?

Less than 10 hours 10 to 19 hours 20 to 29 hours 30 to 40 hours More than 40 hours

32. How many years have you been in your current position?

Less than 1 year 1 to 3 years 4 to 6 years 7-10 years $10+$ years

33. How many years have you worked in school foodservice?

1 year or less 1 to 3 years 4 to 6 years 7-10 years $10+$ years

34. Which of the following best describes your highest education level?

Some high school High school diploma (or equivalent)

Some college Bachelor's degree Graduate degree

35. What is your sex?

Male Female

36. What is your age?

_ 18-25 years old

$$
\text { 26-34 years old }
$$
$35-49$ years old

\section{0-64 years old} 65 years old or older

37. Have you attended USDA Produce Safety University? YES NO

38.Are you a Certified Food Protection Manager (CFPM)? ? YES NO (for example: Servsafe ${ }^{\circledR}$, National Registry of Food Safety Professionals). 


\section{Macrothink}

Thank you very much for sharing your time and information. Please provide any additional comments here:

\section{References}

Ajzen, I. (1985). From intention to actions: A theory of planned behavior. In J. Kuhl, \& J. Beckmann (Eds.), Action -control: From cognition to behavior (pp.11-39). https://doi.org/10.1007/978-3-642-69746-3_2

Arendt, S. W., Paez, P., \& Strohbehn, C. (2013). Food safety practices and manager's perceptions: A qualitative study in hospitality. International Journal of Contemporary Hospitality Management, 25(1), 124-139. https://doi.org/10.1108/09596111311290255

Bartel, A. P. (1991). Productivity gains from the implementation of employee training programs. (No. w3893). National Bureau of Economic Research. https://doi.org/10.3386/w3893

California Department of Education. (2015). Nutrition Services Division. National School Lunch program. Retrieved from http://www.cde.gov/ls/nu/sn/nslp.asp

California Department of Education. (2016). Nutrition Services Division. National School Lunch program. Retrieved from http://www.cde.gov/ls/nu/sn/nslp.asp

California Department of Public Health. (2015). California Retail Food Code._Retrieved from https://www.cdph.ca.gov/services/Documents/fdbRFC.pdf

Centers for Disease Control and Prevention. (2014). CDC and food safety. Retrieved from http://www.cdc.gov/foodsafety/cdc-and-food-safety.html

Center for Disease Control and Prevention. (2015). Preventing future outbreaks. Retrieved from http://www.cdc.gov/foodsafety/outbreaks/preventioneducation/future.html

Delaney, J. T., \& Huselid, M. A. (1996). The impact of human resource management practices on perceptions of organizational performance. Academy of Management Journal, 39(4), 949-969. https://doi.org/10.2307/256718

DeVellis, R. F. (2012). Scale development: Theory and applications. Los Angeles, CA: Sage publications.

Dillman, D. A., Smyth, J. D., \& Christian, L. M. (2009). Internet, mail, and mixed-mode surveys:The tailored design method. Hoboken, NJ: Wiley.

Gould, L. H., Walsh, K. A., Vieira, A. R., Herman, K., Williams, I. T., Hall, A. J., \& Cole, D. (2013). Surveillance for foodborne disease outbreaks-United States, 1998-2008. Morbidity and Mortality Weekly Report Surveillance Summaries, 62(2), 1-34.

Henroid, D., \& Sneed, J. (2004). Readiness to implement Hazard Analysis and Critical Control Point (HACCP) systems in Iowa schools. Journal of the American Dietetic Association, 104(2), 
180-5. https://doi.org/10.1016/j.jada.2003.11.009

Institute of Child Nutrition. (2015). Food safety training. Retrieved from http://www.nfsmi.org/ documentlibraryfiles /PDF/20140509111139.pdf

Jones, A. M., Punia, M., Shannan Young, R. D., Huegli, C. C., \& Zidenberg-Cherr, S. (2013). Training needs of personnel employed in programs participating in the national school lunch program in California. The Journal of Child Nutrition \& Management, 37(1).

Kuder, G. F., \& Richardson, M. W. (1937). The theory of the estimation of test reliability. Psychometrika, 2(3), 151-160. https://doi.org/10.1007/BF02288391

Nunnally, J. C., \& Bernstein, I. H. (1994). Psychometric Theory (3 ${ }^{\text {rd }}$ Ed.). New York, NY: McGraw-Hill.

Painter, J. A., Hoekstra, R. M., Ayers, T., Tauxe, R. V., Braden, C. R., Angulo, F. J., \& Griffin, P. M. (2013). Attribution of foodborne illnesses, hospitalizations, and deaths to food commodities by using outbreak data, United States, 1998-2008. Emerging Infectious Disease Journal, 19(3), 407-415. https://doi.org/10.3201/eid1903.111866

Poulston, J. (2008). Hospitality workplace problems and poor training: A close relationship. International Journal of Contemporary Hospitality Management, 20, 412-427. https://doi.org/10.1108/09596110810873525

Roberts, K. R. (2008). Using the theory of planned behavior to explore restaurant managers' support for employee food safety training (Doctoral dissertation). Retrieved from https://krex.k-state.edu

Roberts, K. R., \& Barrett, B. B. (2011). Restaurant managers' beliefs about food safety training: An application of the theory of planned behavior. Journal of Foodservice Business Research, 14(3), 206-225. https://doi.org/10.1080/15378020.2011.594379

Serving Up Science. (2015). The Center of Excellence for Food Safety Research in Child Nutrition Programs, Kansas State University. Retrieved from http://cnsafefood.k-state.edu/

Sneed, J., \& Strohbehn, C. H. (2008). Trends impacting food safety in retail foodservice: implications for dietetics practice. Journal of the American Dietetic Association, 108(7), 1170-7. https://doi.org/10.1016/j.jada.2008.04.009

Strohbehn, C. H., Arendt, S. W., Ungku, F. U., \& Meyer, J. (2013). Effectiveness of food safety managerial training: Face-to-face or computer-based delivery. Journal of Foodservice Management \& Education, 7(1), 7-19.

Strohbehn, C., Jun, J., \& Arendt, S. (2014). School foodservice employees' perceptions of practice: Differences by generational age and hours worked. The Journal of Child Nutrition \& Management, 38(1).

Thiagarajah, K., Getty, V. M., Johnson, H. L., Case, M., \& Herr, S. J. (2015). Methods and challenges related to implementing the new National School Lunch Program regulations in Indiana. The Journal of Child Nutrition and Management, 39(1). 


\section{Macrothink}

Journal of Food Studies

ISSN 2166-1073 2017, Vol. 6, No. 1

U.S. Department of Agriculture, Food and Nutrition Services. (2004). Child nutrition and WIC reauthorization act of 2004. Retrieved from https://www.fns.usda.gov/sites/default/ files/108-265.pdf

U.S. Department of Agriculture, Food and Nutrition Services. (2014). Healthy hunger free kids act. Retrieved from https://www.fns.usda.gov/school-meals/healthy-hunger-free-kids-act

U.S. Department of Agriculture, Food and Nutrition Services. (2013). National school lunch program fact sheet. Retrieved from http:/www.fns.usda.gov/sites/default/file/NSLP FactSheet.pdf

U.S. Department of Agriculture, Food and Nutrition Services. (2013). Produce safety university. Retrieved from https://www.fns.usda.gov/food-safety/produce-safety-university

U. S. Department of Agriculture, Agriculture Marketing Services. (2016). Good agricultural practices and good handling practices. Retrieved from https://www.ams.usda.gov/ services/auditing/gap-ghp

U.S. Department of Agriculture, Food and Nutrition Services. (2015). Professional standards. Retrieved from https://www.fns.usda.gov/school-meals/professional-standards

U.S. Department of Agriculture, Food and Nutrition Services. (2016). Guide to professional standards for school nutrition programs. Retrieved from https://www.fns.usda.gov $/$ sites/default/files/tn/ps_guide.pdf

U. S. Food and Drug Administration. (2014). Foodborne illness and contaminants. Retrieved from https://www.fda.gov/Food/FoodborneIllnessContaminants/default.htm

\section{Copyright Disclaimer}

Copyright for this article is retained by the author(s), with first publication rights granted to the journal.

This is an open-access article distributed under the terms and conditions of the Creative Commons Attribution license (http://creativecommons.org/licenses/by/3.0/). 